\title{
Educational intentions, cognitive skills and earnings expectations of French undergraduates
}

\author{
Claire Bonnard ${ }^{\mathrm{a}}{ }^{*}$, Jean-François Giret ${ }^{\mathrm{b}}$ and Marielle Lambert-Le Mener ${ }^{\mathrm{b}}$ \\ ${ }^{a}$ CLERSE, University of Lille 1, CNRS and IREDU, University of Burgundy, 21000 Dijon, France \\ bIREDU, University of Burgundy, 21000 Dijon, France
}

Published in Applied Economics Letters, 21 (18), 2014, pp. 1293-1296

http://dx.doi.org/10.1080/13504851.2014.925042

This article aims to study the earnings expectations of first-year students at a French university. Our findings highlight the importance of the environment in which students make their choices about education. Expected earnings are proportionally higher when their parents seem to be involved in the careers guidance, taking into account the effect of parental socio-economic status. The positive opinion of parents about the orientation or the connection between the discipline and the father's occupation are generally associated with higher earnings. In addition, our results show a strong impact of cognitive variables which are far more significant than variables relating to past educational performances.

Keywords: wage expectations; cognitive skills; first year students; LIML estimation

JEL Classifications: J24; I20

I. Introduction

The future level of earnings that young people still in education expect to attain is central to decision-making in the theory of human capital investment. It determines their choices as to their fields of study and so their individual levels of human capital. In the economic literature, student surveys are often used to investigate how wage expectations are constructed (Betts, 1996; Dominitz and Manski, 1996; Brunello et al., 2004). The purpose is to compare students' expected earnings on the labour market with their career plans or with existing jobs in accordance with certain characteristics of the young people: their cognitive abilities during their education, their socio-economic background and the careers guidance they receive. From this perspective, the aim here is to study the earnings expectations of first-year students at a French university. One of the original features of this research is that it includes, as explanatory variables, several measurements of cognitive capacities which it might be thought would influence individuals' expected earnings. Furthermore, although many surveys have been made in both developed and developing countries, none has so far been conducted in France as far as we are aware. Since 2008, French young people have been strongly affected by the rising unemployment rate. It should be asked how young people in the course of their education perceive these difficulties and how the difficulties might affect their choices in terms of investment in human capital? These questions are all the more telling for young people from more modest social backgrounds or from less-favoured areas, who often tend to under- estimate their future earnings and so cut back on their investment in education.

\section{Data}

The survey was conducted in 2010 among first-year stu- dents at the University of Burgundy in three fields of study: social and economic administration, psychology and law. It was conducted in two stages. The first phase was designed to evaluate the abilities of students before they began university. The survey, including tests to mea- sure cognitive abilities, was carried out in the week before the start of the 2010-2011 academic year, during which students were called at random for a mandatory initiation week. The cognitive tests comprised speed processing tasks (Posner tasks), three working memory tests and one reasoning task (the abridged form of Raven's matrices). Lastly socio-demographic and economic data were collected at the start of the research. Some 220 students took the various tests in the first phase. In the second phase, 4 months later, 510 students were asked two questions about their expected earnings and their 
intended level of higher education ${ }^{11}$ :

- What is the highest level of education you plan to achieve by the end of your higher education?

- In your opinion, what will your net monthly earnings be one year after completing higher education?

The average number of years of university education is approximately 4.8, corresponding to mean earnings 1 year after entering the labour market of $€ 1613$. The survey also included information about the students' socio-demo- graphic characteristics, their career choices, their living conditions and their academic achievements. Two other variables were constructed from the survey to try to deter- mine how much students knew about employment opportunities and the labour market. One variable measured the geographical distance between the student's high school and the university and the other the closeness between the father's occupation and the academic discipline chosen by the student.

\section{Method}

We looked to measure the different determinants of expected earnings 1 year after entering the labour market. The intended number of years in higher education is likely to be endogenous in the anticipated wages. To allow for these biases, we estimated limited information maximum likelihood (LIML) instrumental variables regression:

$$
\begin{aligned}
& \ln \left(w^{e s t}\right)_{i}=\beta_{0}+\beta_{e d u c} E d u c_{i}+\beta_{j} X_{i j}+\epsilon_{i} \\
& E d u c_{i}=\gamma_{0}+\gamma_{j} Z_{j i}+\varphi_{i}
\end{aligned}
$$

where $Z_{i}$ were instrumental variables: student's financial resources, self-assessed school performance and the previous year's situation (post-secondary training versus last year high school course). ${ }^{2}$

Given the survey structure, the estimations were performed first on the full sample (510 students) and then on the subsample (169 students) comprising the information on cognitive abilities ${ }^{3}$.Because there were no instruments in the full sample, the simultaneous equations were for the subsample alone.

\section{Results}

Table 1 shows the results of OLS and LIML estimations for the two samples of students. First, the effect of the number of years in higher education on expected earnings at labour market entry is positive and significant, which is consistent with human capital theory. Returns on education nonetheless vary from 3\% to 5\% for the OLS to $11 \%$ for LIML regressions. The unobserved characteristics increase both earnings and the number of years in higher education, which leads to an underestimation of the net effect of the number of years in higher education if it is not endogenized. No variable for secondary school performance turns out to be significant when the scores in certain cognitive tests and the student's self-assessment relative to school level are introduced. Reasoning ability measured by Raven's matrices and the perception of skills positively impact the intended number of years in higher education. Conversely, only the information processing speed, ${ }^{4}$ measured by the Posner test, seems to have a positive and significant impact on expected earnings.

The father's level of higher education and occupation have a fairly limited influence on expected earnings, even if students whose fathers entered higher education intended to undertake longer university studies. However, the connection between the father's occupation and the discipline chosen by young people whose parents were in managerial positions had a 15\% positive impact on expected earnings. This connection had no significant effect for children from more modest social backgrounds. Furthermore, children of parents in managerial positions but whose occupation is unrelated to their studies do not expect higher earnings. These results show that the choice of orientation and the information students have quite strongly structure their expectations about earnings.

\footnotetext{
${ }^{1}$ Information covering the two survey phases was available for 169 students

${ }^{2}$ The F-test on the excluded instruments is larger than the Stock-Yogo 5\% value for the weak identification, based on LIML size. The tests of overidentifying restrictions show that the instruments are correctly specified

${ }^{3}$ To control possible selection bias we estimated a probit to control non responses between two samples, which enabled us to calculate a Mills inverse ratio. As this was not significant, it seems there was no selection bias.

${ }^{4}$ The indicators from these tests are response times in milliseconds, the best performances are therefore the lowest values. The other tests were not included in the model as they were not significant.
} 


\begin{tabular}{|c|c|c|c|c|}
\hline & \multirow{3}{*}{$\begin{array}{l}\text { Full sample } \\
\text { Log of earnings } \\
\text { OLS }\end{array}$} & \multicolumn{3}{|l|}{ Sub-sample } \\
\hline & & \multicolumn{2}{|l|}{ Log of earnings } & \multirow{2}{*}{$\begin{array}{l}\text { Years in higher education } \\
\text { OLS }\end{array}$} \\
\hline & & OLS & LIML & \\
\hline Number of years in higher education & $0.03 * * *$ & $0.05 * * *$ & $0.11 * * *$ & \\
\hline Male & $0.14^{* * *}$ & $0.17 * * *$ & $0.17 * * *$ & -0.13 \\
\hline \multicolumn{5}{|l|}{ Fields of study } \\
\hline \multicolumn{5}{|l|}{ Ref. Psychology } \\
\hline Law & $0.18 * * *$ & $0.10^{* *}$ & $0.10^{* *}$ & 0.21 \\
\hline Administration & $0.13^{* * *}$ & $0.17 * *$ & $0.18^{* * *}$ & -0.32 \\
\hline \multicolumn{5}{|l|}{ Help with orientation in higher education } \\
\hline \multicolumn{5}{|l|}{ Ref. no help } \\
\hline from parents & 0.04 & 0.05 & 0.05 & 0.02 \\
\hline from friends & $-0.07 *$ & -0.10 & -0.09 & -0.16 \\
\hline from others (careers guidance centre, etc.) & -0.04 & -0.08 & -0.08 & 0.37 \\
\hline \multicolumn{5}{|l|}{ Self-assessed school performance } \\
\hline \multicolumn{5}{|l|}{ Ref. average or below } \\
\hline Above average & & & & $0.71 * * *$ \\
\hline \multicolumn{5}{|l|}{ Ref. high school to university from 50 to $150 \mathrm{~km}$} \\
\hline Distance $<50$ & $0.05 *$ & $0.08 * *$ & $0.10^{* *}$ & $-0.38 *$ \\
\hline \multicolumn{5}{|l|}{ Distance $>150$} \\
\hline \multicolumn{5}{|l|}{ Cognitive tests } \\
\hline Raven's matrices & & -0.01 & -0.01 & $0.05^{*}$ \\
\hline Speed processing & & $-0.04 * *$ & $-0.04 * *$ & -0.01 \\
\hline \multicolumn{5}{|l|}{ Father's social category } \\
\hline Father in managerial position (ref. other) & 0.04 & & & \\
\hline \multicolumn{5}{|l|}{ Link between father's occupation and higher } \\
\hline \multicolumn{5}{|l|}{ Ref. father not in management and job unrelated to } \\
\hline Father in management and job related to studies & & $0.13 *$ & $0.15^{* *}$ & -0.20 \\
\hline Father in management and job unrelated to studies & & -0.02 & -0.02 & 0.15 \\
\hline Father not in management and job related to studies & & 0.05 & 0.05 & 0.02 \\
\hline \multicolumn{5}{|l|}{ Career plan } \\
\hline \multicolumn{5}{|l|}{ Ref. no career plan } \\
\hline Plan related to higher education & $0.08 * * *$ & $0.09 * *$ & $0.07 *$ & 0.18 \\
\hline Plan unrelated to higher education & 0.01 & -0.001 & 0.03 & -0.32 \\
\hline \multicolumn{5}{|l|}{ Parents' opinion on orientation } \\
\hline \multicolumn{5}{|l|}{ Ref. unfavourable or no opinion } \\
\hline Favourable opinion & & $0.11^{* * *}$ & $0.10 * * *$ & 0.23 \\
\hline \multicolumn{5}{|l|}{ Ground for university orientation } \\
\hline Ref. other grounds & & & & \\
\hline Choice by interest for subject & & -0.04 & -0.06 & 0.31 \\
\hline Previous year's situation (ref. Post-secondary & & & & \\
\hline Last year high school level & & & & $-0.55 * *$ \\
\hline Main financial resources & & & & \\
\hline Ref. financial resources related to paid activity & & & & \\
\hline Grant student & & & & $0.65 * *$ \\
\hline Direct help from parents & & & & 0.18 \\
\hline Father's level of education & & & & \\
\hline Father had higher education & & -0.003 & -0.03 & $0.41 *$ \\
\hline Left blank & & 0.06 & 0.10 & -0.15 \\
\hline $\mathrm{R}^{2}$ & 0.23 & 0.29 & 0.31 & 0.17 \\
\hline $\mathrm{N}$ & 510 & 169 & & \\
\hline
\end{tabular}

Note: $* * *, * *$ and $*$ Significant at the $1 \%, 5 \%$ and $10 \%$ levels, respectively.

Students with a career plan related to their higher education expect higher earnings. Similarly, students whose parents are in favour of the higher education pursued also expect about $10 \%$ higher earnings. Contrariwise, students whose choice of orientation depends essentially on their friends generally expect lower earnings. In other words, the involvement of the families in the choice of higher education leads young people to aim for higher levels of earnings, most certainly because of better knowledge of the labour market. The distance between the student's former high school and the university has a significant effect, but is more ambiguous because it is not 
linear. When the distance is less than $50 \mathrm{~km}$, students expect slightly higher earnings perhaps because of better knowledge of the skilled labour market in the largest city of the local region or because it is possible to mobilize certain networks. Expected earnings are also higher for students who did their secondary education in high schools far from the university, which may be explained by them wanting to offset the greater cost of higher education by higher earnings.

More classically, other variables like sex or field of study have pretty much expected effects on the expected earnings. Women expect significantly lower earnings than men (about -17\%), which is consistent with earnings differentials observed on the labour market. The field of study effect is important too. Students in law and administration expect significantly higher earnings than those in psychology, a field in which it is reputedly more difficult to find employment. Lastly, students' living conditions determine the intended number of years in higher education. Students whose main financial resource is their grant intend to continue for longer in higher education. Students who benefited from 1 or 2 years in post-secondary institutions want to undertake longer studies. This may be explained by more information on higher education studies.

\section{Conclusion}

This work has sought to understand how first-year university students form expectations about earnings as a function of their intended degree. The results show the importance of the environment in which students make their choices about education. Expected earnings are proportionally higher when their parents seem to be involved in the careers guidance, even controlling for the effect of the socio-economic background or the father's level of education. The positive opinion of parents about the orientation or the connection between the discipline and the father's occupation are generally associated with higher earnings. Conversely, having chosen a course of studies out of a liking for it or further to peer advice seem to have an adverse effect on expected earnings. The results point to a contrast between choices of higher education made in the family context where the continuation in education is an investment and a choice of field of study out of a liking for it where the educational consumption value seems more important. Another point of interest has been to show the impact of cognitive variables is far more significant than variables relating to past educational

performances. Young people seem attuned to the idea that having greater cognitive abilities, for the same diplomas, will enable them to command higher earnings in their future occupational activity.

\section{References}

Betts, J. R. (1996) What do students know about wages? Evidence from a survey of undergraduates, The Journal of Human Resources, 31, 1. doi:10.2307/146042.

Brunello, G., Lucifora, C. and Winter-Ebmer, R. (2004) The wage expectations of European business and economics students, The Journal of Human Resources, 39, 1116-42. doi:10.2307/3559041.

Dominitz, J. and Manski, C. F. (1996) Eliciting student expectations of the returns to schooling, The Journal of Human Resources, 31, 1-26. doi:10.2307/146041. 